ROCZNIKI PEDAGOGICZNE

Tom 12(48), numer $2-2020$

DOI: http://dx.doi.org/10.18290/rped20122-3

MÁRIA MATULČÍKOVÁ

\title{
SÚČASNÉ VYUČOVANIE MEDZI PARADIGMAMI TRADIČNÉHO A PRAGMATICKO-HUMANISTICKÉHO VYUČOVANIA ZAMERANÉHO NA ŽIAKA
}

V reflexii súčasného koncepčného zamerania vyučovania sa prelína viacero aspektov - potreby spoločnosti, novšie výskumy mozgu, vplyv digitálnych technológií, personologické zameranie s prevládajúcim aspektom na žiaka zameraného vyučovania (student celtered learning). Okrem teoreticky zdôvodnených konceptov stále vznikajú nové vyučovacie stratégie, ktoré sa snažia aktivizovat' žiaka, posilnit’ integráciu školského kurikula, či využit' sily vrstovníckeho učenia.

Zároveň však, v praxi vyučovania zostáva verná tradícií J.A. Komenského v zmysle profilácie vyučovania ako slovno-názorného, s dominanciou slovných aktivít učitel'a a čiastočne alebo prevažne pasívnymi učebnými prejavmi žiakov. Komenského požiadavku názornosti sa významne naplńa prezentácia digitalizovaného učiva, pričom, ako je zrejmé, samotná podstata slovno-názorného učenia zostáva zachovaná. To, čo pristupuje ako obohatenie, je posilnenie projektovo orientovaných úloh (často s domácou podporou rodičov), zavádzanie hier a kooperatívnych foriem vyučovania.

Súčast'ou Komenského náhl'adu na vyučovanie bolo chápanie pozície učitel'a, ako vedúcej autority. Bolo súčast'ou dobového chápania usporiadania spoločnosti a logického vyústenia nábožensky poňatej autority rodiča a učitel'a. Liberalizujúce trendy $\mathrm{v}$ praxi vyučovania, ktoré sa masívne prejavujú v praxi súkromných škôl, pomaly prenikajú aj do praxe štátnych škôl a to spolu s liberalizáciou rodinnej výchovy prináša problémy s disciplínou žiakov a nárast prejavov výchovne problémového správania. $\mathrm{K}$ tomu sa pridávajú komplikované vzt’ahy medzi samotnými žiakmi a všeobecne

Doc. PhDr. MÁRIA MATULČÍKOVÁ, CSc.Filozofická fakulta, Univerzity Komenského v Bratislave; e-mail: maria.matulcikova@uniba.sk. 
konštatovaný pokles učebnej motivácie a učebnej výkonnosti (zaznamenávajú ich celoštátne a medzinárodné merania).

V tomto príspevku sa pokúsime na základe východiskovej porovnávacej analýzy tradičného a moderného didaktického konceptu priblí̌zit' špecifičnosti moderného koncept vyučovania, ktorý je v svete známy ako Student centered learning (SCL), ktorá predstavuje jadro novej paradigmy školského vzdelávania. Pokúsime sa reflektovat' faktory, ktoré treba zohl'adnit', aby sa liberalizačné tendencie nestali príčinou poklesu učebnej motivácie a výkonnosti žiakov. V konceptuálnom poňatí vyučovania budeme sledovat' dva aspekty:

1) výchovný (sociálno-didaktický) a

2) didaktický (psychodidaktický a organizačno-metodický).

Stret paradigiem vzdelávania $\mathrm{v}$ rovine výchovy sa $\mathrm{v}$ praxi prejavuje relativizáciou autority a hl'adaním nových prístupov vo vedení vyučovania a zabezpečovaní študijnej disciplíny a sebadisciplíny žiakov. Tradičné prístupy výchovy nahrádzajú procesy facilitácie, koučovania a tútoringu. Na úrovni spoločenstva školskej triedy sa okrem školského poriadku uplatňujú cesty tvorby pravidiel, ktoré utvárajú žiaci a tí sa aj starajú o ich dodržiavanie.

Didaktické prístupy sa v modernom chápaní obracajú na inšpiračné zdroje konštruktivizmu a sociokonštruktivizmu, menej zretel'ná je snaha rozvíjat' aj d’alšie stránky osobnosti - emočnú a vôlovú. Stret paradigiem, tradičnej a modernej, by sme mohli demonštrovat' na porovnaní schém krokov didaktických postupov pri učení sa.

Model konvenčného, tradičného vyučovania, zodpovedajúci tradičnému poňatiu slovno-názorného vyučovania má schémou naznačený systém krokov. Je zrejmé, že názor (pre zmysly), ktorý má podporit’ slovo učitel'a v súčasnej dobe saturujú predovšetkým digitálne technológie. Ak žiaci odpisujú text z prezentácií a následne sa ho učia, vel’mi málo sa zmenila ich prevažne pasívna pozícia vo vyučovaní.

Obr. 1. Schéma slovno-názorného vyučovania podl’a J.A. Komenského

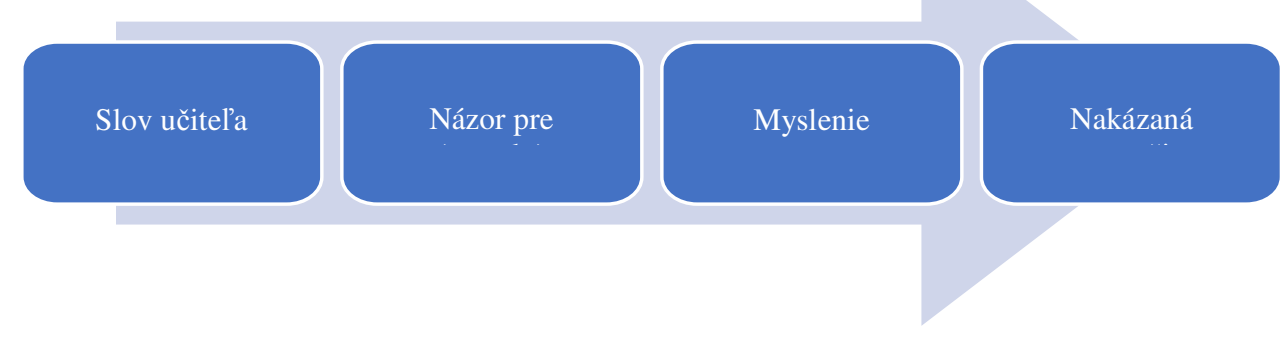


Na druhej strane sa do praxe vyučovania dostávajú moderné prístupy (zväčšia inšpirované alternatívnymi školami (ITI/ HET Susan Kovalikovej, pedagogický model Step by step, a d'alších) dostávajú nové, konštruktivistické prístupy k vyučovaniu, ktoré stavajú na aktívnej pozícii žiaka a menia aj štruktúru vyučovacieho procesu. Ako model, prezentujúci konštruktivistické prístupy môže poslúžit pôvodný Deweyov model učenia sa, ktorý vznikol a rozvíjal sa $\mathrm{v}$ pedagogickom progresivizme $\mathrm{v}$ USA. Je jedným modelov, praktickej aplikácie pedocentrickej orientácie v školskom vzdelávaní, vytvorených v USA a v Európe. Ďalší predstavitelia reformno-pedagogického hnutia vytvorili špecifické modely učenia, ktoré sa navzájom líšili vd’aka špecifickej terminológie a didaktickým prostriedkom (bližšie o tom: Matulčíková, 2007). Schematicky by sme Deweyov model školského učenia (sa) mohli vyjadrit' nasledovne:

Obr. 2. Schéma učenia sa zameraného na žiaka

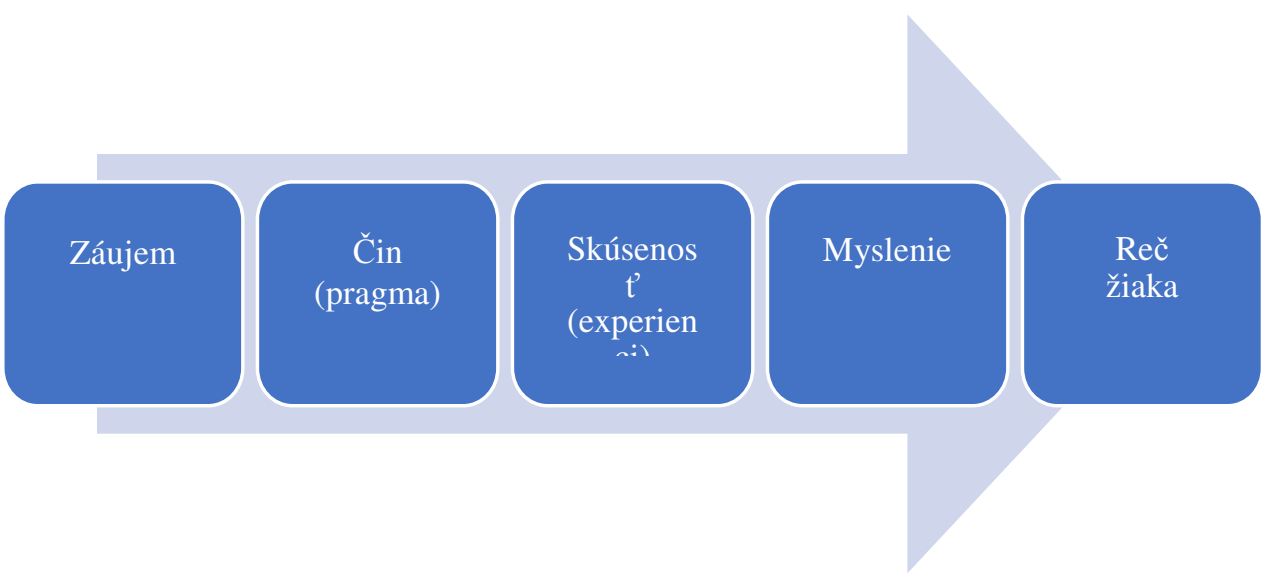

Ako vyplýva zo schémy, koncepčné pohl'ady na proces učenia sa sú navzájom obrátené. Kým činnost' (aktivita žiaka), spojená s učením sa je $\mathrm{v}$ tradičnom na konci učenia sa, v pragmatickom, pedocentrickom modeli je na začiatku. Je dôležité poznamenat', že tradičné vyučovanie môže dosahovat' vysokú efektivitu, pokial' je vedené v atmosfére uznávanej autority učitel'a. Vzt'ah devócie a dôvery napomáha l'ahšiemu didaktickému transferu, reprodukcie a produkcie nových vedomostí.

Vzhl'adom na spoločenské podmienky a mnohozdrojovost' poznania, ktoré môže žiak samostatne získat', zvonka sa mení vzt'ah medzi učitel'om a žiakom, založený na autorite, na partnerský vzt’ah. Psychologický základ tohto vzt’ahu reprezentuje humanistická psychológia s konceptom „na žiaka 
zameraného učenia“ - Student centered learning ( d'alej SCL). Ide o didaktický prístup, ktorý sa presadzuje v modernej didaktickej teórii a v praxi vyučovania žiakov od základnej školy až po univerzitu. Vysoká škola, univerzita, je typom didaktického prostredia, kde sa prístup SCL javí ako najpotrebnejší.

\section{TEORETICKÉ ZÁKLADY STUDENT CENTERED LEARNING (SCL)}

Prakticky vo všetkých demokraticky rozvinutých krajinách silnie záujem o zmenu paradigmy v školskom vzdelávaní, záujem o zmenu, ktorá je výstižne vyjadrená požiadavkou prepnutia od vyučovania - učitel'a k učeniu sa žiaka. Kritický posun v školskom vzdelávaní smerom od učitel'a a kurikula k žiakovi, má už niekol'koročné tradície a priniesol pedagogickej teórii a praxi viacero didaktických stratégií, ako napríklad kooperatívne/ kolaboratívne učenie, objavné učenie, projektovo a bádatel'sky zamerané vyučovanie vrstovnícke učenie (peer instruction), flexibilné učenie, zmiešané učenie (blended learning), učenie sa zamerané na učiaceho sa, na žiaka zamerané učenie (learner centered learning, student centered learning).

Za nestora moderného konceptu SCL je bez akýchkol'vek pochybností považovaný John Dewey. Jeho pedocentrická orientácia nachádza legitimitu nielen z aspektu vnútorného sveta žiaka (jeho učebného záujmu), ale aj z každodenných skúseností školskej triedy, ktorú J. Dewey chápal ako mikročast' spoločnosti (škola ako zárodok spoločnosti). Požadoval prirodzené učenie sa, vychádzajúce zo záujmov diet'at'a, zdiel'anú skúsenost' považoval za jadro učenia sa a východisko rozvoja myslenia. Aj preto bol zástancom vekovej heterogenity žiakov a rôznorodosti inteligencie, lebo rôznost' byt' obohacuje zdiel'anú skúsenost', a tá je pre učenie sa najdôležitejšia. Bol zástancom Haecklovej evolučnej teórie, podl'a ktorej diet'a v individuálnom vývine opakuje vývin l'udstva. Špecifické, historicky podmienené činnosti (napríklad stavanie chatrčí), podporujú vývin učebnej motivácie. Jeho prínos pre pedagogiku je vyjadrovaný krédom „learning by doing“, manuálne a kooperatívne činnosti boli základom konceptu vyučovania $\mathrm{v}$ otvorených učebných priestoroch. Je považovaný za zakladatel'a problémového vyučovania a myšlienkového iniciátora vzniku projektového vyučovania.

Samotné pomenovanie pedagogického modelu SCL vzniklo na podnet druhého z najvýznamnejších zakladatel'ov, ktorý spracoval predovšetkým vzt’ahovú (výchovnú) stránku model SCL, a bol ním humanistický psychológ, C.R. Rogers. 


\section{CARL R. ROGERS}

Je známy predovšetkým ako zakladatel’om humanistického prístupu v psychoterapii, ktorý rozpracoval teóriu a prax na osobnost' zameraného prístupu (PCA). Následne sa venoval aj aplikácii svojej teórie v pedagogickej praxi a popri vzt’ahových otázkach svojej inovačnej pedagogickej sa tiež venoval otázkam organizácie a metodiky vyučovania.

$\mathrm{V}$ pedagogike, podobne ako $\mathrm{v}$ psychoterapii uznával účinnost' dvoch tendencií, ktoré určujú vývin človeka a $\mathrm{v}$ širších súvislostiach aj vývin l'udstva. Ide o tendenciu aktualizačnú a formatívnu. „V každom organizme, nech je na l'ubovol'nej úrovni vývinu, je skryté neustále smerovanie k tvorivému naplneniu bytostne vlastných možnosti. Aj v l'ud'och je prítomná prirodzená tendencia k všestrannejšiemu a plnšiemu rozvoju“ (Rogers, 2014, s. 123). Každé pedagogické pôsobenie by malo byt' v súlade s touto tendenciu, čo je napokon v súčasnosti všeobecne prijímané, aspoň v deklaratívnej podobe ako princíp indivduálneho prístupu k žiakovi. Popri aktualizačnej tendencii C: Rogers ešte uvádzal „formatívnu tendenciu“, ktorú vymedzil (podobne, ako M. Montessoriová vývinovú silu „hormé“) ako súčast’ tvorivej sily univerza. Jeho formatívna tendencia znamená, že ako l’udia „ladíme s mocnou tvorivou tendenciou, ktorá splodila vesmír, od najdrobnejšej snehovej vločky až po tie najobrovskejšej galaxie, od tej najjednoduchšej améby, až po najcitlivejších a najnadanejších l'udí“ ( tamže, s. 137). Carl Rogers je v pedagogike d'alším predstavitel'om, ktorý verí a počíta s inteligenciou autonómneho rozvoja osobnosti každého človeka a sústred’uje pozornost' na podmienky, ktoré majú zabezpečit' tento vývin. Vo svoje podstate sa tento vývin napíña v l'udských vzt'ahoch a preto Rogers apeloval na to, aby prežívané vzt’ahy boli plnohodnotné a tým sa vyhli riziku odcudzeniu a následne zabrzdeniu sebarealizačných tendencií, ktoré v l’udksje psychike imanentné. Aj tu sa ponúka paralela s pedagogikou teóriou M. Montessoriovej, ktorá upozorňovala na význam pripraveného prostredia dôležitosti osobnosti učitel'ky/ učitel'a.

C. Rogers za kl'účové považoval l'udský vzt’ah a atmosféru pedagogického procesu. V súvislosti s učitel'om vo vzdelávaní (podobne, ako je to s terapeutom $\mathrm{v}$ terapii) formuloval tri nevyhnutné a postačujúce podmienky zabezpečenia zdravého vývinu žiakov:

$1 /$ kongruencia (autenticita),

$2 /$ bezpodmienečné prijatie (s nehodnotením) a

3/ empatia (Rogers, 2014). 
Tieto fenomény pokladal sa súčast' profesionality pedagóga (terapeuta) a rozpracoval ich do podoby pedagogických schopností, kompetencií.

Kongruencia znamená v prvom rade súlad cítenia s myslením a konaním (tamže, s. 29). Na označenie tohto stavu bytia sa používajú aj označenia: úprimnost', skutočnost', otvorenost', autenticita. Je zrejmé, že človek nemôže byt' vo všetkých životných situáciách kongruentný, to znamená konat' tak, ako cíti, alebo myslí. Podstatné je vedomé úsilie o kongruenciu, najmä v terapeutických a pedagogických vzt'ahoch. Integrovanost' osobnosti, kongruencia prináša benefity aj pre samotného učitel'a, poskytuje mu možnost' poznávat' seba samého a stávat' sa bytost'ou sociálne konštruktívnou. Lebo len vnímavost' voči vlastnému fenomenálnemu svetu, ktorý je dostupný cez vlastné prežívanie, umožní vedomé spracovanie jeho obsahu a vyjadrit' ho v komunikácii, či v praktickom konaní. Kongruencia jedného človeka pomáha druhému: „Ked’ sa mi podarí byt' kongruentným a skutočným, často tým pomôžem druhému človeku. Ak je ten druhý očividne skutočným a kongruentným, často naopak pomôže on mne (tamže, s. 33). V kongruencii má významné postavenie prežívanie a postoje, tie umožňujú stavat' sa do l'udských vzt'ahov celou osobnost'ou. Prežívanie potom poskytuje dôležité informácie aj pre myslenie a konanie. Kongruencia umožňuje, aby vzt'ahy medzi l'ud'mi boli založené na dôvere a vzájomnom rešpekte.

Bezpodmienečná akceptácia ako schopnost' učitel'a, či znak pedagogickej situácie umožňuje žiakom slobodné prežívanie, umožňuje disponovat' a vyjadrovat' vlastné názory. Bezpodmienečná akceptácia napomáha $\mathrm{k}$ rozvoju sebaakceptácie a sebaúcty. Akceptujúce porozumenie umožňuje žiakovi (klientovi) porozumiet' vlastným pocitom bez hanby sa sebaodsúdenia, a napomáha tomu, aby mohol byt' človek (žiak, študent) kongruentnejší. Bezpodmienečná akceptácia prežívania $\mathrm{v}$ pedagogickej praxi neznamená diktát študentov, alebo rezignáciu na ciele vyučovania, či zneváženie pozície učitel'a. Kongruencia, uplatňovaná s bezpodmienečnou akceptáciou umožňuje učitel'ovi nielen formulovat' dôsledky konania žiaka na prežívanie iných, alebo jeho vlastné. Umožňuje tiež obracat' pozornost' na ciele výučby a pravidlám správania sa, na ktorých sa spolu dohodli. Vel'kou témou bezpodmienečnej akceptácie je zrieknutie sa hodnotenia. Návyk hodnotit' prejavy žiakov je v pedagogickej praxi silne zakorenený. V koncepte SCL ho nahrádza poskytovaním spätnej väzby, ktorá ako súčast' bezpodmienečnej akceptácie umožňuje utvárat' skutočné vzt'ahy a realizovat' osobnostné zmeny. Spätná väzba je myslená ako objektívny obraz konania žiaka a jeho výsledkov. 
Empatia je osobnostná vlastnost', ktorá učitel'ovi umožňuje, aby všetkými možnými zmyslami vstúpil do sveta prežívania žiaka. Je často chápaná ako reflektované cítenie druhého, zrkadlenie, chápajúca odozva, verbalizácia emočného prežívania druhého človeka (Mikoška, 2016, s. 58). Je schopnost’ou, ktorá je úzko prepojená s bezpodmienečnou akceptáciou a kongruenciou. Napíńa sa v l’udskej komunikácii a jej základným prejavom je aktívne počúvanie. Aktívne počúvanie znamená vnímanie osobnosti druhého človeka s tým, že je vylúčený akýkol'vek vlastný názor, alebo hodnotenie. Empatia je výrazom vzt’ahu, ktorý vedie $\mathrm{k}$ zážitku hodnoty Ja druhého človeka a v druhom človeku podporuje rozvoj sebaúcty. Empatia neznamená rezignáciu na práva vlastné, alebo práva iných. Práve empatia umožňuje pol’udštenie procesov riešenia konfliktov, osobnostných, aj medzinárodných. Prežívanie a empatia je mocným nástrojom akademického učenia. Zapojením emocionálnej stránky vyučovania sa podporuje rozvoj kognitívnych aspektov vyučovania. Podceňovaním prežívania, poznávanie bez pocitov vedie $\mathrm{k}$ odcudzeniu v l'udskom správaní, $\mathrm{k}$ negatívnym dopadom $\mathrm{v}$ hodnotovej orientácii jednotlivcov. C. Rogers uvádza príklady bombardovania Vietnamu a Kambodže, ktoré nariadili a vykonali l'udia s rozvinutým intelektom bez toho, aby si uvedomili emocionálny dopad vlastného konania na iných l'udí. Píše o totálnom spôsobe učenia sa, ktorý by mal odvrátit' takéto konanie v budúcnosti. Ak by sa intelektuálny pojem, napr. bombardovanie, spájal s prežívanou hrôzou zasiahnutých, vytvorili by sa morálne zábrany v konfliktoch konat' takýmto spôsobom (Rogers, c.d., s. 260).

\section{VYUČOVANIE AKO VZŤAH}

V zmysle Rogersovej teórie osobnostne zameraného prístupu, je vyučovanie chápané ako stretnutie viacerých l’udí, pri ktorom dochádza $\mathrm{k}$ vystúpeniu $\mathrm{z}$ vlastného referenčného rámca a $\mathrm{k}$ dešifrovaniu vlastných subjektívnych skúseností. Je to stretnutie, kde sa aktualizujú l'udské osobnosti a vzdelávací obsah je zdiel'aný, nie odovzdávaný. V zmysle Rogersových tendencií a nevyhnutných podmienok slobodného rozvoja jednotlivca v spoločenstve sa do popredia dostávajú procesy prežívania a na svoje protiklady sa menia klasické znaky vyučovacieho procesu. Miesto učitel'a sa do centra pozornosti dostáva žiak, žiaci, disciplína sa stáva výsledkom práce na vzájomných vzt’ahoch, s využitím podpory vnútornej učebnej motivácie. Ak aj nie je možné odstránit’ školského hodnotenie, mení sa podobu, posilnená je najmä 
priebežná spätná väzba. Chápanie chyby, ako prirodzenej súčasti je d’alším faktorom, ktorý podporuje učebnú motiváci. Rogers svoje chápanie vyučovania vymedzil silne kriticky voči prevládajúcemu systému školského vzdelávania v USA. P. Mikoška zhŕňa, že stručne by sa jeho koncept vyučovania mohol označit’ predponou ,anti“ voči všetkým znakom tradičného vyučovania (Mikoška, 2016, s. 70).

Pri charakteristike Rogersovho modelu vyučovania (SCL) je treba uviest', že overoval na väčšom počte škôl. Známy je Louisvillský program, išlo o reformu školského vyučovania v rámci celého mesta. Samotný Rogers vysoko hodnotil úspešnost' projektu a popísal aj následné byrokratické, politicky motivované príčiny ukončenia reformného projektu (Rogers, 2014, s. 279). Na kritické výhrady voči uvol'nenej disciplíne na vyučovaní reagoval popisom skúseností, ktoré ukázali, že po počiatočnom chaose, istom šoku zo slobody, sa žiaci dostali do vyrovnaného študijného tempa. Na obavy zo straty efektivity vyučovania reagoval upozornením na význam práce s učebnými ciel'mi a štrukturácie učebných procesov. To je dôležité zvlášt' pre univerzitný stupeň vzdelávania.

V strednej Európe, v Mad'arsku sa nachádza škola, ktorá model aplikuje od roku 1993, v pedagogickom programe sa hlási k rogersovským filozoficko-psychologickým základom. Ide o združenú školu (má zriadenú materskú školu, základnú školu a gymnázium) a je to Szines iskola v Tate (Organ Szines-iskola. Nevelési Program 2020). Model tejto školy uvádza vo svojej monografii M. Zelina (2000, s. 52-55). Citovaný autor model školy hodnotil pozitívne. Podobne možno spomenút' základnú školu v Pol’sku (Oborniki).

Postupom času sa k základom humanistickej pedagogiky C. Rogersa pridávali nové vedecké poznatky a pedagogické prístupy. Upozornit' treba na koncept emocnionálnej inteligencie (D. Goleman), koncept konštruktivizmus a sociokonštruktivizmu. (L. Vygotskij) a v posledných rokoch predovšetkým aplikované poznatky modernej neurovedy (Ginnis, 2018, s. 14-35).

V súčasnosti sa koncept SCL vymedzuje prostredníctvom sústavy znakov, prípadne princípov, ich sústavu prezentuje obr. 3. (Kaput, 2018, s. 1) obra. 3 Príloha - pictures.

1/ Žiaci a učitelia (dospelí) sú navzájom prepojení vzt'ahmi starostlivosti, dôvery a vysokých očakávaní.

2/ Biologické, psychologické potreby, potrebu bezpečia nevynímajúc sú u žiakov napíňané

3/ Žiaci sú prijímaní takí, akí sú a rozvíjajú si pozitívny sebaobraz (identitu) so spolupatričnost'ou 
4/ Žiaci majú slobodu výberu v nasledovaní svojich záujmov, od učitelov dostávajú facilitačnú podporu a vedenie

5/ Žiaci riešia reálne situácie zo života a získavajú schopnosti, ktoré im pomôžu vo vlastnom živote

6/ Žiaci majú možnost' preukazovat' vysoké výsledky a dostávajú primeranú podporu

7/ Žiaci sa učia aj mimo školy - na exkurziách, stážach, cez víkendy atd’.

Obr. 3. Sústava znakov SCL. Zdroj: htps://files.eric.ed.gov/fulltext/ED 581111.pdf

Didaktické aspekty SCL - organizácia a metodika vyučovania

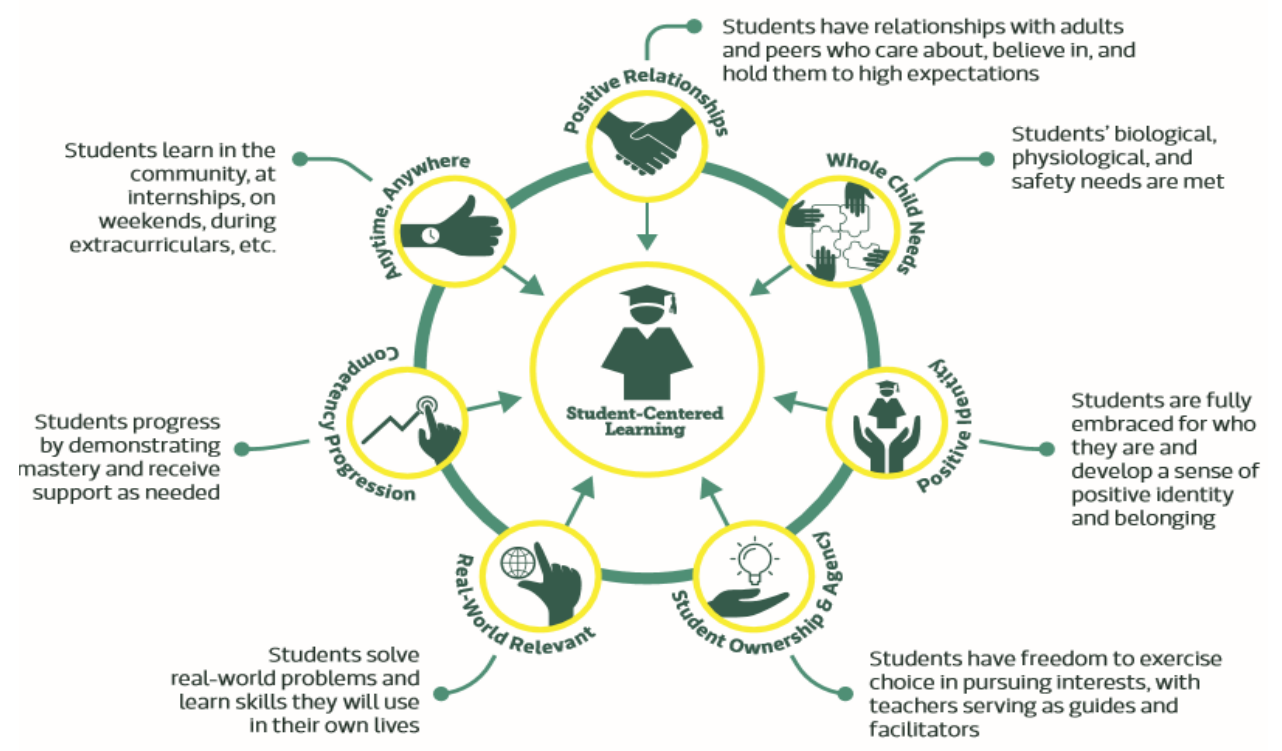

Pre prax vyučovania podl'a konceptu SCL je najdôležitejšie, aby bola vytvorená pozitívna atmosféra, podporujúca učenie. Nový typ komunikácie a vzt'ahov medzi učitel'mi a žiakmi realizovaný na báze rešpektu, má potenciál uspôsobit' študentov k tomu, aby dokázali prevziat' zodpovednost' za vlastné učenie sa. C. Rogers vo svojich pôvodných dielach dokonca žiadal, aby boli žiaci zapojení do rozhodovania o kurikulárnych a organizačných otázkach vyučovania ( Mikoška, 2016 s . 125). 
Na obavy z možného zníženia študijnej výkonnosti žiakov a študentov reagoval popisom vlastných skúseností, podl'a ktorých sa po dočasnom uvol'není tlaku kontroly učitel'ov dostavilo uvol'nenie disciplíny a neistota $v$ študijnom úsilí študentov. Tá však vd’aka facilitujúcemu spôsobu vyučovania, postupne vytrácala a študenti začali systematicky pracovat' na témach, ktoré boli aj vd’aka ich participácii dobre štruktúrované. V tejto súvislosti C. Rogers viackrát zdôrazňoval význam spoločnej práce na ciel'och výučby. Aj ked' sa v počiatočných fázach učebného procesu líšia ciele študentov a učitel'ov, reflexia významu ciel'ov učenia má významný dopad na vznik pozitívnej učebnej motivácie žiakov (tamže).

\section{METODIKA VYUČOVANIA}

Ak sa v prípade tradičného konceptu vyučovania učitel' v metodike vyučovania opiera o sústavu vyučovacích metód, ktoré sú najčastejšie vymedzované ako: slovné, názorno-demonštračné a aktivizujúce, v SCL sa k metodike vyučovania pristupuje inak. Rozdiely sú už v pomenovaní sústavy metód a potom aj v ich praktickom využití. P. Ginnis, jeden z dvojice autorov príručky o SCL píše o aktivitách a nástrojoch rozvoja osobnosti žiakov. Praktická príručka z roku 2018 obsahuje učebné aktivity pre skupinovú a individuálnu prácu, d’alej nástroje na rozvoj tímovej spolupráce v skupinách a na prevzatie zodpovednosti za učenie, d’alej nástroje sebakontroly a celého manažovania učenia sa a $v$ neposlednom rade aj nástroje na realizáciou diferencovaného prístupu ku žiakom. V rámci projektu POGIL, čo je prístup CSL, rozvíjaný v podmienkach prírodovedného učenia sa zdôrazňujú postupy, zamerané na rozvoj kompetencií žiakov: ústna a písomná komunikácia, tímová práca, riešenie problémov, kritické myslenie, riadenie a sebariadenie, práca s informáciami, hodnotenie a sebahodnotenie (Optimalized POGIL Process Skill).

Ako vyučovacie stratégie pre vyučovanie v systéme SCL sa odporúčajú nasledovné metódy (https://www.teachthought.com): učenie, skupinková práca, jigsaw, práca v centrách aktivít, debaty, panelové a expertné diskusie, hry a sút'aže, práca so sociálnymi médiami, projektové učenie, problémové učenie, objavné učenie, mentálne modely, rolové hry, simulácie, kazuistiky, laboratórne práce, demonštrácie, prezentácie, tvorba médií, skladačky. V zmysle Rogerovho chápania SCL, vol’ba vyučovacích metód má až sekundárny význam. 


\section{ZÁVER}

Prax vyučovania v základných a stredných školách sa mení. Popri zápase o dobré skórovanie $\mathrm{v}$ medzinárodných testovaniach, PISA, TIMS, PIRLS a d'alších, rastie počet a rozširuje sa spektrum sociálno-patologických javov v škole. Podl'a vyjadrení odborníkov, narastá agresívne správanie sa voči učitel'om. S. Bellová, G. Siváková, K. Tišt’anová (2019) uvádzajú viditel'né prejavy neúcty voči učitelovi a nežiadúce prejavy správania, tie sa stávajú súčast'ou každodenného života $\mathrm{v}$ škole. Značné riziko $\mathrm{v}$ tomto smere predstavuje aj kybernetický priestor. Podl’a výsledkov výskumu z ČR (Kopecký, Szotkowski, a kol. 2016, s. 7-21) sa obet'ou niektorých z foriem kyberšikanovania stalo 21\% učitel'ov (vyjadrené v absolútnych číslach: 1118 učitel'ov z 5136).

Aj tieto, aj ked' iba ilustračné výskumné údaje svedčia o potrebe pracovat' na sociálnych vzt'ahoch $\mathrm{v}$ škole. Jednoznačne sa ukazuje, že sa zmenil koncept detstva a dospievania mladistvých (podrobnejšie: Matulčíková, 2010). Deti a mladiství sú si vedomí svojich práv a uplatňujú si ich (nie vždy aj povinností). Spoznávajú svet, predovšetkým virtuálny bez sprostredkovatel'ov (dospelých). Sú schopní získat' informácie a poznanie aj bez učitel'ov, sú konfrontovaní s prelínaním reálneho a virtuálneho, rastú do sveta, v ktorom je t'ažisko hodnôt posunuté smerom k prosperite a pohodliu, stávajú sa konzumentami nenáročnej kultúry. Podmienky života $v$ rodine a $\mathrm{v}$ škole sa stávajú takými odlišnými, že otvárajú socializačný rozpor medzi výchovou $\mathrm{v}$ rodine a v škole. Doma majú neporovnatel'ne viac možností rozhodovat' sa, vyjednávat' s rodičmi a svojimi rozhodnutiami ovplyvňovat' dianie. Okolo seba, ako v škole. Intuitívne ovládanie médií a spotrebičov v domácnosti sa dostáva do protikladu so systémom správania sa a poznávania v škole - v nej z logických dôvodov prevládajú mechanizmy formálnej organizácie. Zrejme dozrel čas na to, aby odborníci otvorili diskusiu o tom, ako súčasný profil vyučovania naplńa pedagogické potreby detí, do akej miery môže nadväzovat' a nadväzuje na rodinnú výchovu a ako má regovat' na nový koncept detstva a dospievania mladistvých. SCL je dobrým inšpiračným zdrojom a môže byt' východiskom pre odborné diskusie. 


\section{LITERATÚRA}

Bellová., S., SivÁKovÁ, G.,TišŤAnovÁ, K. (2019). Aspekty nevhodného správania žiakov voči učitel’om v slovenských školách. In: Pedagogická revue, č. 1. s. 73-83.

Brandes, D., GinNis, P. (1994). A Guide to Student-centered Learning. Cheltenham: Neilson Lid.

GinNis, P. Efektivní výukové nástroje pro učitele. Strategie pro zvýšení úspěšnosti každého žáka. Praha: Univesum.

Goleman, G. (2011). Emoční inteligence. Praha: Metafora.

Organ Szines-iskola. Nevelési Program. [cit. 09.02.2020] http://www.szines-iskola.hu/fajl/peda gogiai_program.pdf.

Fishman, S.M., Certhy, Mc.L. (1998). John Dewey and the Challenge of Classroom Practice. Teachers College Columbia University New York \& London.

GajdošovÁ, E., HeréNYIOvÁ, G. (2002). Škola rozvíjania emocionálnej inteligencie žiakov. Bratislava: Príroda.

KAPUT, K. (2018). Evidence for Student-Centered Learning ERIC Number: ED581111. [cit. 09.02.2020] Retireved: https://eric.ed.gov/?id=ED581111.

KOPECKÝ, K., SzOTKOWSKI, R. (2016). Specifické formy kyberšikany učitelů v prostředí základních a středních škôl. Olomouc [cit. 09.02.2020] Retrieved: http://oldwww.upol.cz/fileadmin/ user_upload/PdF/veda-vyzkum-zahr/2016/seminare/Specificke_formy_kybersikan y_ucitelu_text.pdf.

MATULČíKOVÁ, M. (2007). Reformno-pedagogické a alternatívne školy. Bratislava: Musica Liturgica.

MATULČíkovÁ, M. (2010). Štúdiá o det'och a detstve - konceptuálne a obsahové otázky = Child and childhood study - innovation for theory, research and practice. In: Paedagogica 22, s. 57-77.

Optimalized POGIL Process Skill Definition 2015 [cit. 09.02.2020] Retrieved: https://pogil.org/ uploads/attachments/cj54b5yts006cklx4hh758htf-process-skills-official-pogil-list-2015-origi nal.pdf.

Student-Centered Instructional Strategies. Instructional methods. 2018 [cit. 09.02.2020]. Retireved: https://www.teachthought.com/pedagogy/28-student-centered-instructional-strategies/.

TomengovÁ, A. (2012). Aktívne učenie sa žiakov-stratégie a metódy. Bratislava: MPC.

ROGERS, C.R. (2014). Způsob bytí: klíčová témata humanistické psychologie z pohledu jejího zakladatele. Praha: Portál.

ZelinA, M. (2000). Alternatívne školstvo. Bratislava: Iris.

\section{SÚČASNÉ VYUČOVANIE MEDZI PARADIGMAMI TRADIČNÉHO A PRAGMATICKO-HUMANISTICKÉHO VYUČOVANIA ZAMERANÉHO NA ŽIAKA}

RESUMÉ

V reflexii súčasného koncepčného zamerania vyučovania sa prelína viacero aspektov: ekonomické potreby spoločnosti, novšie výskumy mozgu, vplyv digitálnych technológií, personologické prístupy k vyučovaniu s dôrazom na koncept vyučovania zameraného na žiaka (SCL).

V tomto príspevku sa pokúsime na základe východiskovej porovnávacej analýzy tradičného a moderného didaktického konceptu priblížit' špecifičnosti konceptu Student centered learning (SCL). Predmetom analýzy budú teoretické základy SCL a praktické otázky jeho aplikácie v školskej výchove, didaktické otázky organizácia a metodiky vyučovania v rámci SCL.

Kl’účové slová: paradigma vzdelávania; pragmaticko-humanistické vzdelávanie; Student centered learning; Instructional startegies of Student centered learning. Author. 


\section{WSPÓŁCZESNE NAUCZANIE POMIĘDZY PARADYGMATAMI TRADYCYJNEGO I PRAGMATYCZNO-HUMANISTYCZNEGO NAUCZANIA SKONCENTROWANEGO NA UCZNIACH}

\section{STRESZCZENIE}

Zastanawiając się nad obecnym koncepcyjnym ukierunkowaniem nauczania, nakłada się kilka aspektów: potrzeby ekonomiczne społeczeństwa, nowsze badania mózgu, wpływ technologii cyfrowych, personologiczne podejścia do uczenia się, z naciskiem na koncepcję uczenia się skoncentrowanego na uczniu. W tym artykule postaramy się podejść do specyfiki koncepcji uczenia się zorientowanej na ucznia (SCL - Student centered learning) w oparciu o wstępną analizę porównawczą tradycyjnej i nowoczesnej koncepcji dydaktycznej. Przedmiotem analizy będą teoretyczne podstawy SCL i praktyczne pytania dotyczące jego zastosowania w edukacji szkolnej, dydaktyczne pytania dotyczące organizacji i metodyki nauczania w SCL.

Słowa kluczowe: koncepcja edukacji; edukacja pragmatyczno-humanistyczna; uczenie się zorientowane na ucznia; strategie nauczania oparte na uczeniu się zorientowanym na ucznia.

\section{CONTEMPORARY TEACHING BETWEEN THE PARADIGMS OF TRADITIONAL AND PRAGMATIC-HUMANISTIC STUDENT-CENTERED TEACHING}

\section{SUMMARY}

Reflecting on the current conceptual focus of teaching, several aspects overlap: the economic needs of society, newer brain research, the impact of digital technologies, personological approaches to learning with emphasis on the concept of student-centered learning. In this paper, we will try to approach the specifics of the student-centered learning concept (SCL), based on the initial comparative analysis of traditional and modern didactic concept. The subject of the analysis will be theoretical foundations of SCL and practical questions of its application in school education, didactic questions of organization and teaching methodic within SCL.

Key words: education concept; pragmatic-humanistic education; student-centered learning; instructional strategies of student-centered learning. 